\section{Creating Regimes}

Arctic Accords and International Governance

ORAN R. YOUNG

Oran R. Young weaves together theoretical issues relating to the formation of international regimes and substantive issues relating to the emergence of the Arctic as a distinct region in world affairs. 3 drawings, 2 graphs, 1 map. $\$ 35.00$

\section{The}

\section{International} Origins of the Federal Reserve System

\section{J. LAWRENCE BROZ}

Until the passage of the Federal Reserve Act of 1913, the United States had suffered under one of the most inefficient payment systems in the world - serious banking panics erupted frequently, and nominal interest rates fluctuated wildly. Probing the origins of this Act, J. Lawrence Broz finds that international factors were crucial to its conception and passage, and that to those who organized the political effort to pass the Act, the creation of the Federal Reserve System was first and foremost a response to international opportunities. 20 tables, 6 charts/graphs. $\$ 35.00$

\section{The Currency of Ideas}

Monetary Politics in the European Union

KATHLEEN

R. MCNAMARA

Why have the states of Europe agreed to create an Economic and Monetary Union (EMU) and a single European currency? What will decide the fate of this bold project? This book explains why monetary integration has deepened in Europe from the Bretton Woods era to the present day. Cornelt Studies IN Political Economy. 9 tables, 7 charts/graphs. $\$ 29.95$

\section{Tamed Power}

Germany in Europe

EDITED BY PETER

\section{J. KATZENSTEIN}

Revolutionary changes in European politics have reawakened old fears that Europe will be dominated by an unpredictable German giant. The same changes have fueled new hopes for Germany and Europe as models of political pluralism. Yet Peter J. Katzenstein contends that a multilateral institutionalization of power is the most distinctive aspect of the relationship between Europe and Germany. 3 tables, $\$ 49.95$ cloth, $\$ 19.95$ paper

At bookstores, or call (607) 277-2211

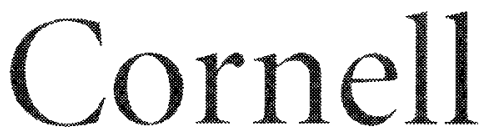

\begin{tabular}{lllllllllllll}
$U$ & $N$ & $I$ & $E$ & $R$ & $S$ & $I$ & $T$ & $Y$ & $R$ & $E$ & $S$ & $S$ \\
\hline
\end{tabular} Sage Honse 512 Last State Street - Ithaca NK 14850

\section{GLENN H. SNYDER}

"Alliance Politics is an immediate classic . . laying out the general structural logic and tensions of alliance formation and managein style. Snyder's writing is a model of clarity." - Edward Rhodes, Rutgers University Cornell Studies in Security Affairs 20 charts/graphs, 16 tables $\$ 39.95$

\section{Negotiating the New Germany}

\section{Can Social Partnership Survive? \\ EDITED BY \\ LOWELL TURNER}

The reunification of Germany in 1990 juxtaposed two very different models of industrial relations: West Germany with a largely collaborative relationship between business and labor, codified in law, and East Germany with a long-standing, authoritarian system. Would western-style social partnership spread to all of Germany, or would it find itself seriously destabilized? This volume assesses both models and the results of their union. AN ILR Press Book. 10 tables, 5 charts/ graphs. $\$ 45.00$ cloth, $\$ 17.95$ paper ment. The book is also a classic 

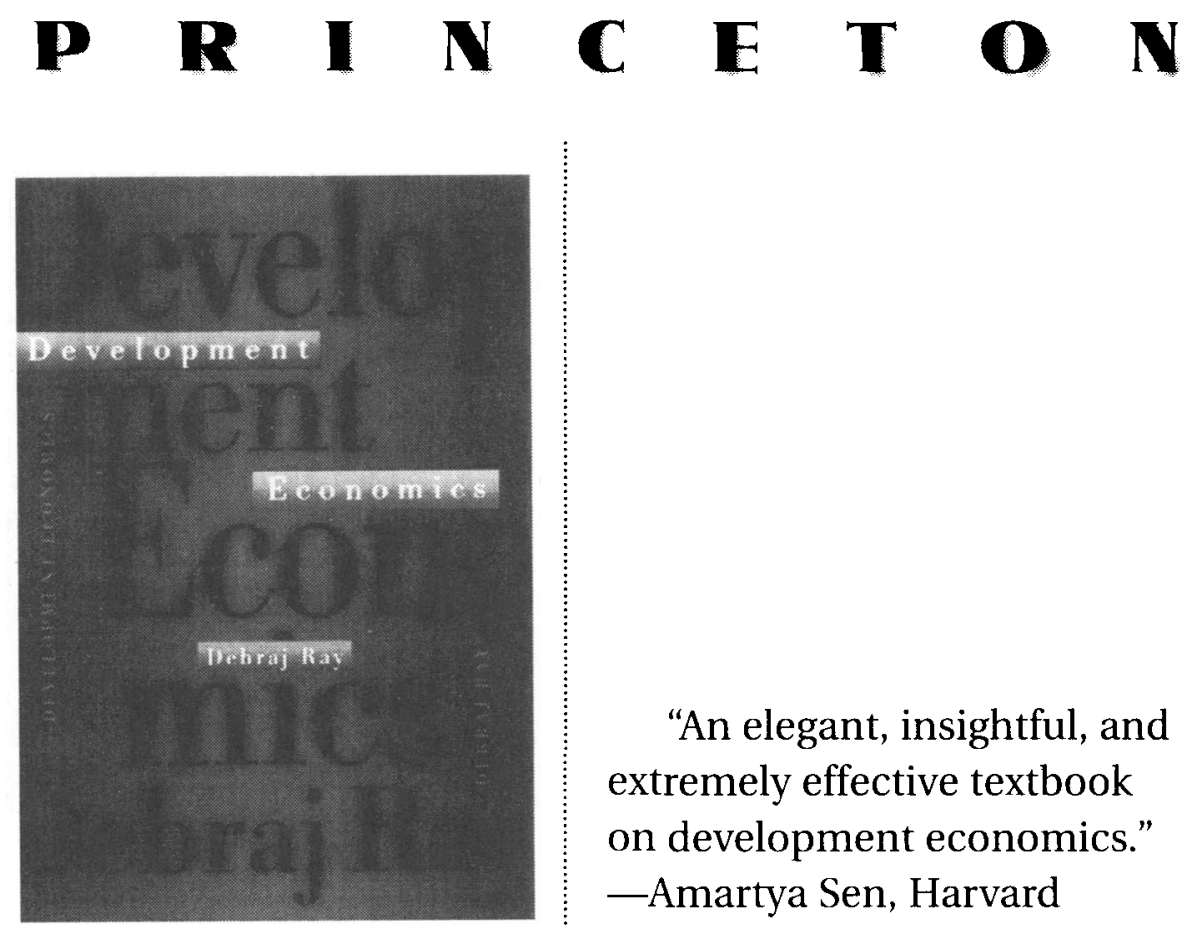

\section{Development Economics Debraj Ray}

The study of development in low-income countries is attracting more attention around the world than ever before. Yet until now there has been no comprehensive text that incorporates the huge strides made in the subject over the past decade. Development Economics does precisely that in a clear, rigorous, and elegant fashion. It will be the definitive textbook in this subject for years to come. Cloth \$55.00 ISBN 0-691-01706-9

"An elegant, insightful, and extremely effective textbook on development economics." -Amartya Sen, Harvard University

"The best textbooks spring from a coherent intellectual vision and a deeply felt passion. Development Economics is such a book."

-Paul Romer, Stanford University

"Debraj Ray has written a splendid book that brings a unified intellectual framework to the myriad disparate topics that constitute development economics."

-Angus Deaton, Princeton University 


\section{$\mathbf{P}$

\section{The International Spread} of Ethnic Conflict

Fear. Diffusion, and Escalation

\section{Edited by David A. Lake} and Donald Rothchild

In this volume, David Lake and Donald Rothchild have organized an ambitious, sophisticated exploration of both the origins and spread of ethnic conflict, one that will be useful to policymakers and theorists alike.

"Scholarly, theoretical, and quantitative. It significantly advances the scholarly literature in the field and, in doing so, opens new prospects for policy analysis as well."

-Roy Licklider

Paper \$18.95 ISBN 0-691-01690-9

Cloth $\$ 60.00$ ISBN 0-691-01691-7

\section{The Myth of the Global}

\section{Corporation}

\section{Paul N. Doremus,}

William W. Keller, Louis W. Pauly, and Simon Reich

There is widespread agreement today that multinational corporations are creating a global market, which is rendering national borders obsolete. Backed by a wealth of new evidence, the authors of this book argue persuasively that this belief is a myth. For anyone who is trying to make sense of the "global economy," this is essential read. ing.

"This is an important contribution to scholarship on the multinational firm and the subject of international political economy."-Robert Gilpin Cloth \$29.95 ISBN 0-691-03636-5

\section{From Wealth to Power}

The Unusual Origins of

America's World Role

\section{Fareed Zakaria}

What turns rich nations into great powers? How do wealthy countries begin extending their influence abroad? In From Wealth to Power, Fareed Zakaria seeks to answer these questions by examining the most puzzling case of a rising power in modern history-that of the United States.

"The theory of state-centered realism set forth in From Wealth to Power is the most important innovation in years in foreign-policy theory."-Samuel P. Huntington

"Beautifully conceived; dazzlingly executed. . . ."-Kenneth N. Waltz

Princeton Studies in International History and Politics Jack L. Snyder and Richard H. Ullman, Editors Cloth $\$ 29.95$ ISBN 0-69l-04496-1

\section{Changing Course}

Ideas. Politics, and the Soviet Withdrawal from Afghanistan

\section{Sarah E. Mendelson}

Soviet foreign policy changed dramatically in the 1980s. In Changing Course, Sarah Mendelson demonstrates that both ideas and political strategies were needed to make reform happen.

"Mendelson does a brilliant job in capturing the political contingency central to the explanation of change. She offers a new conception, new interpretations, and original data based on an extraordinarily broad and comprehensive set of interviews." -Janice Stein Princeton Studies in International History and Politics Cloth $\$ 35.00$ ISBN 0-691-01677-1

\section{Princeton University Press}




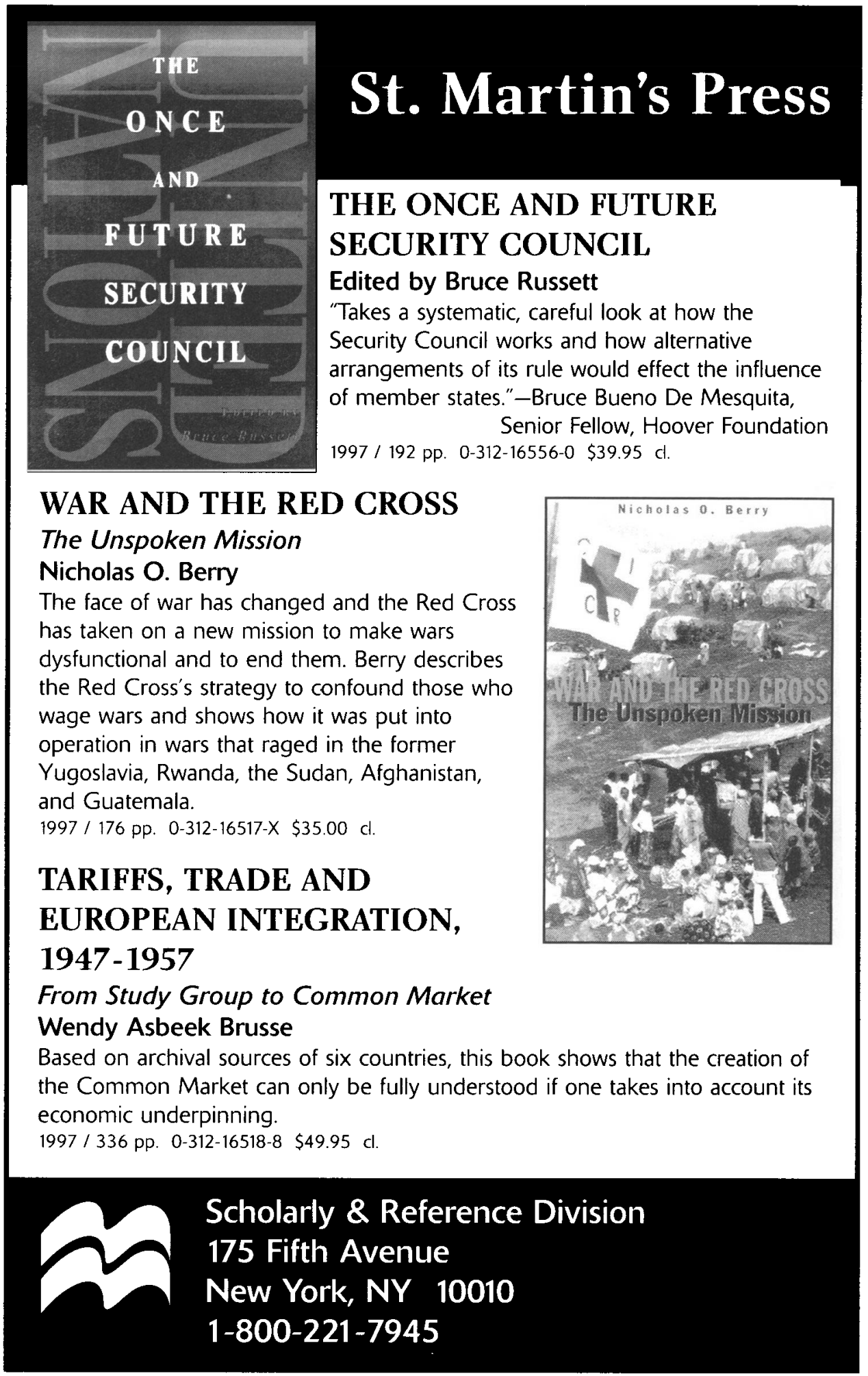




\section{Studies in International Relations}

Charles W. Kegley, Jr., and Donald J. Puchala, series editors

New for Spring

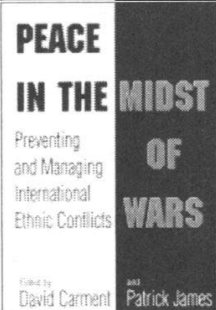

Peace in the Midst of Wars

Preventing and Managing

International Ethnic Conflicts

of Edited by David Carment \& Patrick James

An important and timely book that explores the intractable problem of ethnic conflict - the defining characteristic of international relations after the Cold War. cloth, \#1-57003-217-3, \$39.95

New in paperback

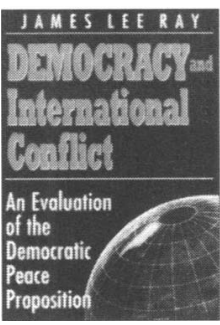

Democracy and International Conflict

An Evaluation of the

Democratic Peace Proposition

James Lee Ray

The author defends the idea that democratic states do not initiate war against one another and therefore offer an avenue to universal peace.

paper, \#1-57003-241-6, \$16.95

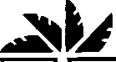 \\ University of South Carolina Press}

718 Devine Street, Columbia, South Carolina 29208

(800) 768-2500 • FAX (800) 868-0740

Visit our web site at www.sc.edu/uscpress

\section{This Publication} is available in Microform.

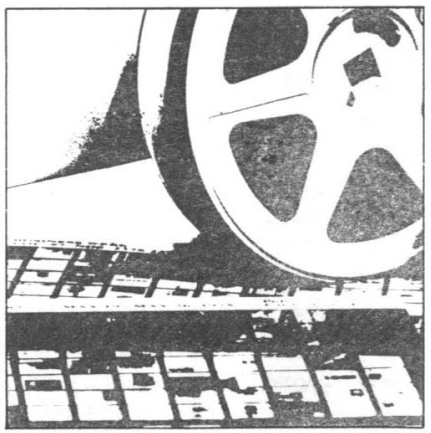

University

Microfilms

International

Please send additional information

for

Namic iname of putlicalion!

Institution

Street.

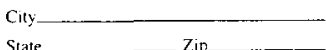

300 North Zeeb Road

Dep1. P.R

Ann Arbor. Mi. 48106 


\title{
International $\mathbf{O}_{\text {rganization }}$
}

\author{
- Back Issues -
}

\section{Select Featured Articles}

Vol. 33, Nos. I, 3, and 4

Vol. 35, Nos. 2, 3 and 4

Vol. 36, Nos. 1, 3 and 4

Vol. 38, Nos. 1-4

Vol. 39, Nos. I and 4

Vol. 40, Nos. 1 and 3

Vol. 4I, Nos. I, 3 and 4

Vol. 42, No. 2, Spring 1988

NATO and the Persion Gulf: Examining Intra-olliance Behovior Charles A. Kupchan

\section{Vol. 43, No. I, Winter 1989}

The Impact of Ideas on Trade Policy: The Origins of U.S. Agricultural and Manufacturing Policies Judith Goldstein

Vol. 44, No. 3, Summer 1990 Multilateral Negotiations: A Spatial Anolysis of the Arab-israeli Dispute Bruce Bueno de Mesquita

Vol. 44, No. 4, Autumn 1990

How Japan Affects the International System Henrik Schmiegelow and Michèle Schmiegelow

Vol. 45, No. 2, Spring 1991

The East European Countries and GATT: The Role of Realism, Mercantilism, and Regime Theory in Explaining Eost-West Trade Negotiotions Leah Haus

Yol. 45, No. 3, Summer 1991 Political Leadership and Regime Formation: On the Development of Institutions in Internotional Society Oran R. Young
Vol. 46, No. I, Winter 1992 SPECIAL ISSUE: Knowledge, Power, and International Policy Coordination Edited by Peter M. Hass

Vol. 46, No. 3, Summer 1992 SYMPOSIUM: Multilateralism with john Gerard Ruggie, James A. Caporaso, Steve Weber, Miles Kahler

Vol. 46, No. 4, Autumn 1992

From Competition to Colloboration: The Challenge of Commercial-Class Aircroft Manufocturing Vicki L. Golich

Vol. 47, No. 1, Winter 1993

Domestic Reform and International Change: The Gorbachev Reforms in Historical Perspective Valerie Bunce

Vol. 47, No. 2, Spring 1993

The International Labor Organization and the Welfare State: Institutional Effects on National Welfore Spending, 1960-80 Dayid Strang and Patricia Mei Yin Chang

Vol. 47, No. 3, Summer 1993 Human Rights, Principled issue-Networks, and Sovereignty in Latin America Kathryn Sikkink

\section{Vol. 47, No. 4, Autumn 1993} Europeons and the European Community: The Dynamics of Public Support for European Integrotion Richard C. Eichenberg and Russell J. Dalton

Vol. 48, No. I, Winter 1994 Burden-shoring in the Persion Gulf Wor Andrew Bennett, Joseph Lepgold, and Danny Unger
Vol. 48, No. 2, Spring 1994 SYMPOSIUM:The End of the ColdWar and Theories of Intermational Relations

Vol. 48, No. 3, Summer 1994 Free Trade, Foir Trade, Strotegic Trade, and Protectionism in the U.S. Congress, 1987-88 Stanley D. Nollen and Dennis P. Quinn

Vol. 48, No. 4, Autumn 1994 The Change of Tide in Political Cooperation: A Limited Informotion Model of European Integration Gerald Schneider and Lars-Erik Cederman

Vol. 49, No. I, Winter 1995

A Genealogy of the Chemical Weopons Toboo Richard Price

\section{Vol. 49, No. 2, Spring 1995}

Openings in the Wall: Transnational Migrants, Labor Unions, and U.S. Immigration Policy Leah Haus

Vol. 49, No. 3, Summer 1995 Sovereignty, Nationalism, and Regional Order in the Arob States System Michael N. Barnett

Vol. 49, No. 4, Autumn 1995 Hierarchy Under Anarchy: Informol Empireandthe East Germon Stote Alexander Wendt and Daniel Friedheim

Vol. 50, No. 1, Winter 1996 Anarchy, Hierarchy and the Variety of Internotionol Relotions David A. Lake Democrocy and Peoce: Putting the Cort Before the Horse? William R. Thompson

Vol. 50, No. 2, Spring 1996 Wor and Strong States, Peace and Weak States? Michael C. Desch The Partisan Paradox and the U.S. Tariff, 1877-1934 David Epstein and Sharyn O'Halloran 
Vol. 50, No. 3, Summer 1996

Is the Good News About Compliance Good News About Cooperation? George W. Downs, David M. Rocke, and Peter N. Barsoom NATO's Persistence After the Cold Wor Robert B. McCalla

Vol. 50, No. 4, Autumn 1996 International Low and Domestic Institutions: Reconciling North American "Unfoir" Trade Laws Judith Goldstein The New Politics of Voting Alignments in the United Nations General Assembly Soo Yeon Kim and Bruce Russett
Vol. 5I, No. I, Winter 1997

National Structures and Multinational Corporate Behavior: Enduring Differences in the Age of Globalization Lovis W. Pauly and Simon Reich

Perceptions and Alliances in Europe, 1865-1940 Thomas J. Christensen

Vol. 51, No. 2, Spring 1997

The Fragmentation and Consolidation of International Systems Stuart J. Kaufman

Americon Identity and Neutral Rights from Independence to the Wor of 1812 Mlada Bukovansky
Vol. 5I, No. 3, Summer 1997

The Critical Barrier to Civil War Settlement Barbara F. Walter

Chasing Phantoms: The Political Economy of USTR Marcus Noland

\section{Vol. 51, No. 4, Autumn 1997}

The Constitutionol Structure of International Society and the Noture of Fundamentol Institurions Christian Reus-Smit The Structuring of a World Environmental Regime, 1870-1990 john W. Meyer. David John Frank, Ann Hironaka, Evan Schofer, and Nancy Brandon Tuma

\section{International $\mathrm{O}_{\text {rganization }}$}

\section{- Back Issues Order Form -}

Please send me the following back issue(s):

$$
\begin{aligned}
& { }^{33: 1}{ }^{39: 1}{ }^{39: 1}{ }^{46: 1}{ }^{39: 4} \\
& { }^{33: 3}{ }^{339: 4} \text { - }^{36: 3} \quad{ }^{49: 4}
\end{aligned}
$$

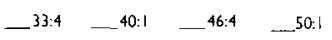

$$
\begin{aligned}
& { }^{35: 2}-40: 3 \quad-47: 1 \quad 50: 2 \\
& { }_{35: 3}^{35}-41: 1 \quad{ }^{47: 2}{ }^{40: 3}
\end{aligned}
$$

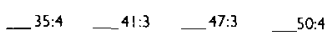

$$
\begin{aligned}
& -36: 1 \quad{ }^{41: 4} \text { - }^{47: 4}{ }^{51: 1} \\
& { }_{36: 3}^{36}{ }^{42: 2}{ }^{48: 1}{ }^{48: 2} \\
& { }^{36: 4}{ }^{43: 1}{ }^{43}{ }^{48: 2}-51: 3 \\
& { }^{38: 1}{ }^{48: 3}{ }^{48: 3}{ }^{48: 3}{ }^{41: 4} \\
& { }^{38: 2} \text { - }^{44: 4}{ }^{48: 4} \\
& \text { - } 38: 3 \quad-45: 2 \quad-49: 1 \\
& { }^{38: 4}{ }^{45: 3}{ }^{49: 2}
\end{aligned}
$$

Prices subject to change without notice. Prepayment required.

Send check or money orderdrawn on a U.S. bank in U.S. funds, payable to International Organization- AMEX. MC, or VISA number to:

\section{Circulation Department \\ MIT PRESS JOURNALS}

Five Cambridge Center CAMBRIDGE, MA 02142 USA

TEL: (617) 253-2889

FAX: (617) 577-1545

journals-orders@mit.edu

TOTAL

\section{Check or money order-drawn on a U.S. bank in U.S. funds, payable to International Organization-is enclosed.}

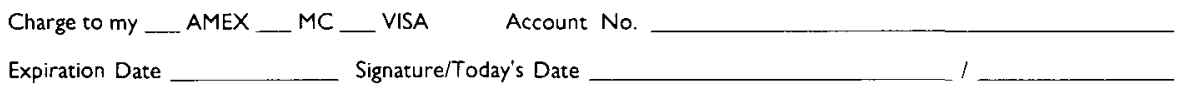

Print carcholder's name

Send to (please print clearly):

Name

Company/Department

Address

City/State/Province/ZIP/Country 


\title{
Nou' published by Harwood Academic Publishers!
}

\section{Journal of European Integration}

\section{Revue d'Intégration Européenne}

\author{
Executive Editor: Emil Kirchner \\ University of Essex, Department of Government, Wivenhoe Park, Colchester, CO4 3SQ \\ Tel: +44 (0)1206872 749•Fax: +44 (0)1206873598•E-mail: emil@essex.ac.uk
}

The journal publishes articles with a focus on European integration and an interdisciplinary or multidisciplinary perspective, thus integrating politics, economics, law, history, and sociology. European integration is understood as pan-European rather than as merely the $\mathrm{EU}$, though the bulk of contributions might be devoted to the latter. It occasionally presents comparative studies of federalism, other forms of regional integration, and articles dealing with EU external relations, whether in the trade or security policy field.

The main purpose of the journal is to serve a wide readership, which implies that articles should be of a general rather than a specific or specialized nature. In other words, whilst the emphasis should be on scholarly work (analysis rather than description), it should provide explanations regarding the process of integration in a historical and comparative fashion, and avoid specific or highly specialized writings.

All submissions will undergo a rigorous peer-group review process. Issues on exclusive subjects and nonspecific issues are published in no particular order. Contributions are published in English or French.

\section{A Selection of Papers}

- European Citizenship From Maastricht to Amsterdam: The Narrow Path of Legitimation, Paul Magnette

- Denmark's Maastricht Ratification Case: Some Serious Questions About Constitutionality, Hjalte Rasmussen

- "Bringing Process Back In": The Longue Durée of European Integration, Thomas Christiansen

- Towards Regional Convergence in the European Information Society?, Gerhard Fuchs and Hans-Georg Wolf

ISSN: 0703-6337 - 4 issues per volume • Current Subscription:Volume 21 (1998) • Harwood Academic Publishers

E-mail: info@gbhap.com•Visit Our Home Page: http://www.gbhap.com

For further information, pricing details or to order, please contact:

North/South America: IPD, Box 32160, Newark, N] 07102, USA - Tel: +1 8005458398 - Fax: +12157506343

Europe/Middle East/Africa: IPD Marketing Services Ltd., P.O. Box 310, St. Helier, Jersey JE4 OTH, Channel lslands Tel: +44 (0)1189560080 Fax: +44 (0)1189568211 


\section{KEEP INFORMED!}

Whether your main interest is in international relations, business, or finance, you can't afford to be without the timely, authoritative, and influential articles in INTERNATIONAL ORGANIZATION. Don't wait for borrowed copies or hurry to return them. Order your personal subscription today and join the experts in universities, embassies, corporations, and international think tanks who must read INTERNATIONAL ORGANIZATION to keep informed of today's shifting alliances and international market activity.

\section{International Organization}

_ This is a new subscription.

_- This is a renewal. My account number is (see label) Your subscription will begin with the first issue of the current volume.

_ This is a gift. (Please attach recipient's name/address as well as your own.)

$\begin{array}{lccc}1998 \text { RATES (check one) } & \text { U.S. } & \text { Canada* } & \text { All Other Countries } \\ \text { Individual } & -\$ 42 & \$ 44.94 & -\$ 58 \\ \text { Institution } & -\$ 120 & -\$ 128.40 & -\$ 136 \\ \text { Student**/Retired } & -\$ 26 & -\$ 27.82 & -\$ 42 \\ \text { "Price reflects 7\% GST. } & \text { "Copy of current ID required }\end{array}$

\section{Prepayment required}

Check or money order enclosed, payable to International Organization.

(check must be drawn against a U.S. bank in U.S. funds)

$\begin{array}{ll}\text { Charge to my __ MasterCard __ VISA _ AmEx } & \text { Expiration Date } \\ \text { Account No. } & \text { Today's Date }\end{array}$

Print cardholder's name

Send the subscription to: (please print clearly)

Name Daytime phone

Company/Dept. E-mail

Address

City/State/Province/Zip/Country

\section{International Organization}

\section{CHANGE OF ADDRESS FORM}

As soon as you know your new address, please mail this card. If possible, tape an old address label over name and old address sections and complete new address section. Please print clearly.

Name

Old address:

Company/Dept.

Address

City/State/Province/Zip/Country

Daytime phone E-mail

New address:

Company/Dept.

Address

City/State/Province/Zip/Country

Daytime phone

E-mail 


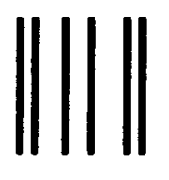

NO POSTAGE

NECESSARY

IF MAILED

IN THE

UNITED STATES

\section{BUSINESS REPLY MAIL \\ FIRST CLASS MAIL PERMIT NO. 309 BOSTON, MA}

POSTAGE WILL BE PAID BY ADDRESSEE

\section{MIT Press Journals}

Five Cambridge Center

Cambridge, MA 02142-9902

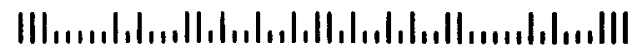

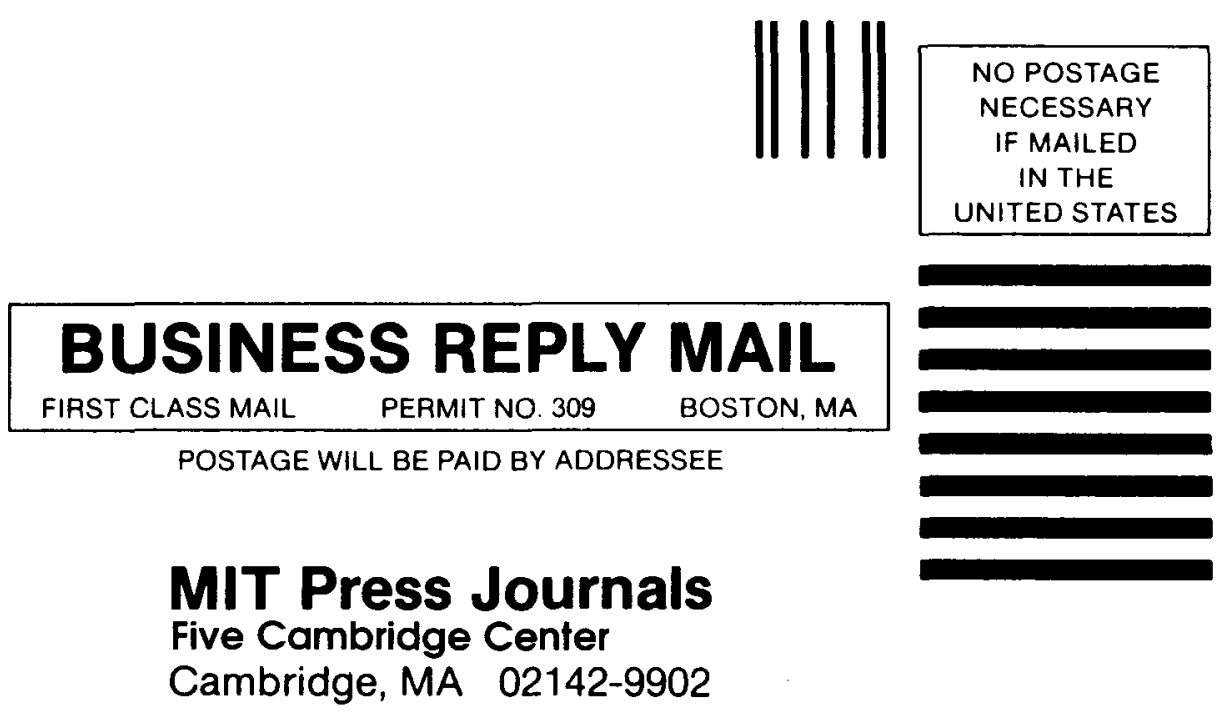

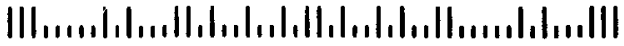


International Organization (ISSN 0020-8183) is published quarterly (winter, spring, summer, and autumn) by The MIT Press, Five Cambridge Center, Cambridge, MA 02142. Subscriptions and address changes should be addressed to MIT Press Journals, Five Cambridge Center, Cambridge, MA 02142; telephone (617) 253-2889; fax (617) 577-1545; e-mail: journals-orders@mit.edu. Subscriptions are on a volume year basis. Rates are: Individual $\$ 42.00$, Institutions $\$ 120.00$, Students/Retired $\$ 26.00$. Outside U.S. and Canada add $\$ 16.00$ for postage and handling. Canadians add $7 \%$ GST. Current issues are $\$ 32.00$. Back issues are: Individuals: $\$ 16.00$, Institutions $\$ 32.00$. Outside U.S. and Canada add $\$ 5.00$ per issue for postage and handling. Canadians add 7\% GST. Claims for missing issues will be honored free of charge if made within three months after the publication date of the issue. Prices subject to change without notice. Postmaster: Send address changes to International Organization, Five Cambridge Center, Cambridge, MA 02142. Periodicals postage paid at Boston and additional mailing offices.

International Organization is abstracted or indexed in the following: Academic Abstracts, ABC Pol Sci, America: History and Life, Applied Social Sciences Index \& Abstracts, Communication Abstracts, Current Contents/Social \& Behavioral Sciences, Current Law Index, Deep Sea Research \& Oceanographic Abstracts, Energy Research Abstracts, Expanded Academic Index, Future Survey, Historical Abstracts, Human Rights Internet Reporter, INIS Atomindex, Index of Economics Articles, International Bibliography of Economics (also in IBSS), International Bibliography of Periodical Literature, International Bibliography of the Social Sciences/Political Science, International Labour Documentation, International Political Science Abstracts, Journal of Economic Literature, Key to Economic Science, Legal Research Index, Magazine Index (Information Access Company), Middle East: Abstracts and Index, Public Affairs Information Service/PAIS, Recently Published Articles, Rural Recreation and Tourism, SCIMP (Selective Cooperative Index of Management Periodicals), Social Sciences Citation Index, Social Sciences Index, Social Science Source, Sociological Abstracts, World Agricultural Economics \& Rural Sociology Abstracts.

Advertising and mailing list rental: Please write to Marketing Department, MIT Press Journals, Five Cambridge Center, Cambridge, MA 02142 USA, or telephone (617) 253-2866, fax (617) 258-5028, e-mail: journals-info@mit.edu.

Rights and permissions: All inquiries concerning rights and permissions should be sent to Subsidiary Rights Manager, MIT Press Journals, Five Cambridge Center, Cambridge MA 02142; telephone (617) 253-2864; fax (617) 258-5028; e-mail: journals-rights@ mit.edu. Permission to photocopy articles for internal or personal use or the internal or personal use of specific clients is granted by The IO Foundation and the Massachusetts Institute of Technology for libraries and other users registered with the Copyright Clearance Center (CCC), provided that the fee of $\$ 8.00$ per copy is paid directly to CCC, 222 Rosewood Drive, Danvers, MA 01923. The fee code for users of the Transactional Reporting Services is 0020-8183/98 \$8.00. For those organizations that have been granted a photocopy license with $\mathrm{CCC}$, a separate system of payment has been arranged. 


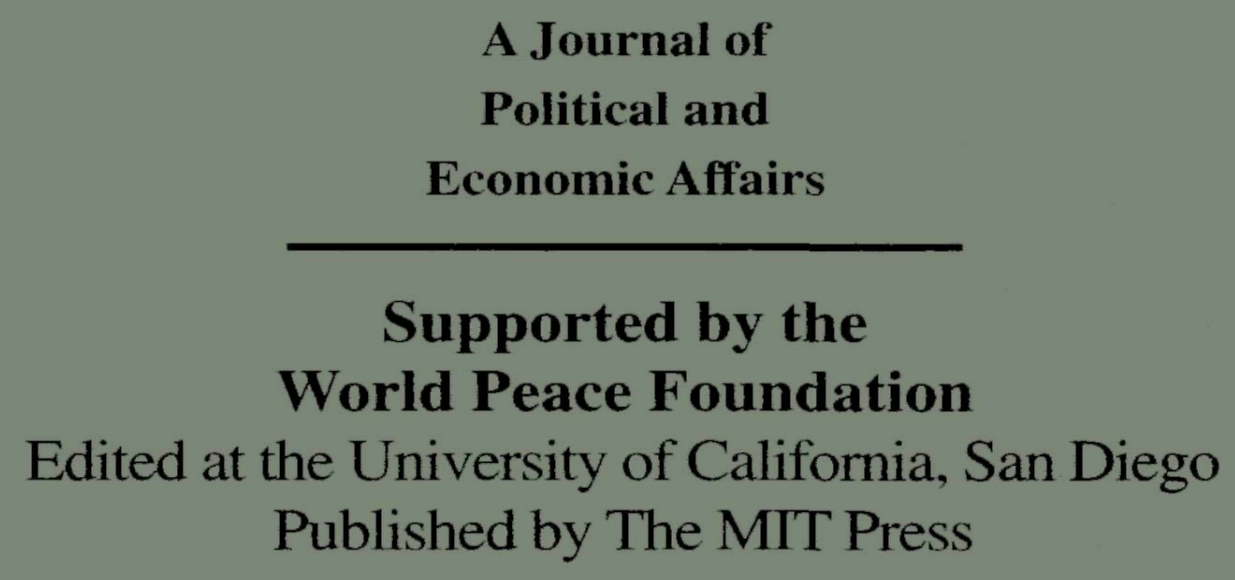

